International Journal of Public Health Excellence (IJPHE)

Vol. 1, No. 1, January 2022, pp. 21 26

Journal homepage: https://ejournal.ipinternasional.com/index.php/ijphe/

ISSN: 2809-9826, DOI: https://doi.org/10.55299/ijphe.v1i1.5

\title{
The Determinants of Behavior Of HIV Testing in Pregnant Mothers
}

\author{
Meilani Harahap ${ }^{1}$ Nikmatul Khoiriyah Pulungan ${ }^{2}$ Ennysah Hasibuan ${ }^{3}$ \\ ${ }^{1,2,3}$ D3 Midwifery Study Program, Padangsidimpuan Matorkis Midwifery Academy, Padangsidimpuan, Indonesia
}

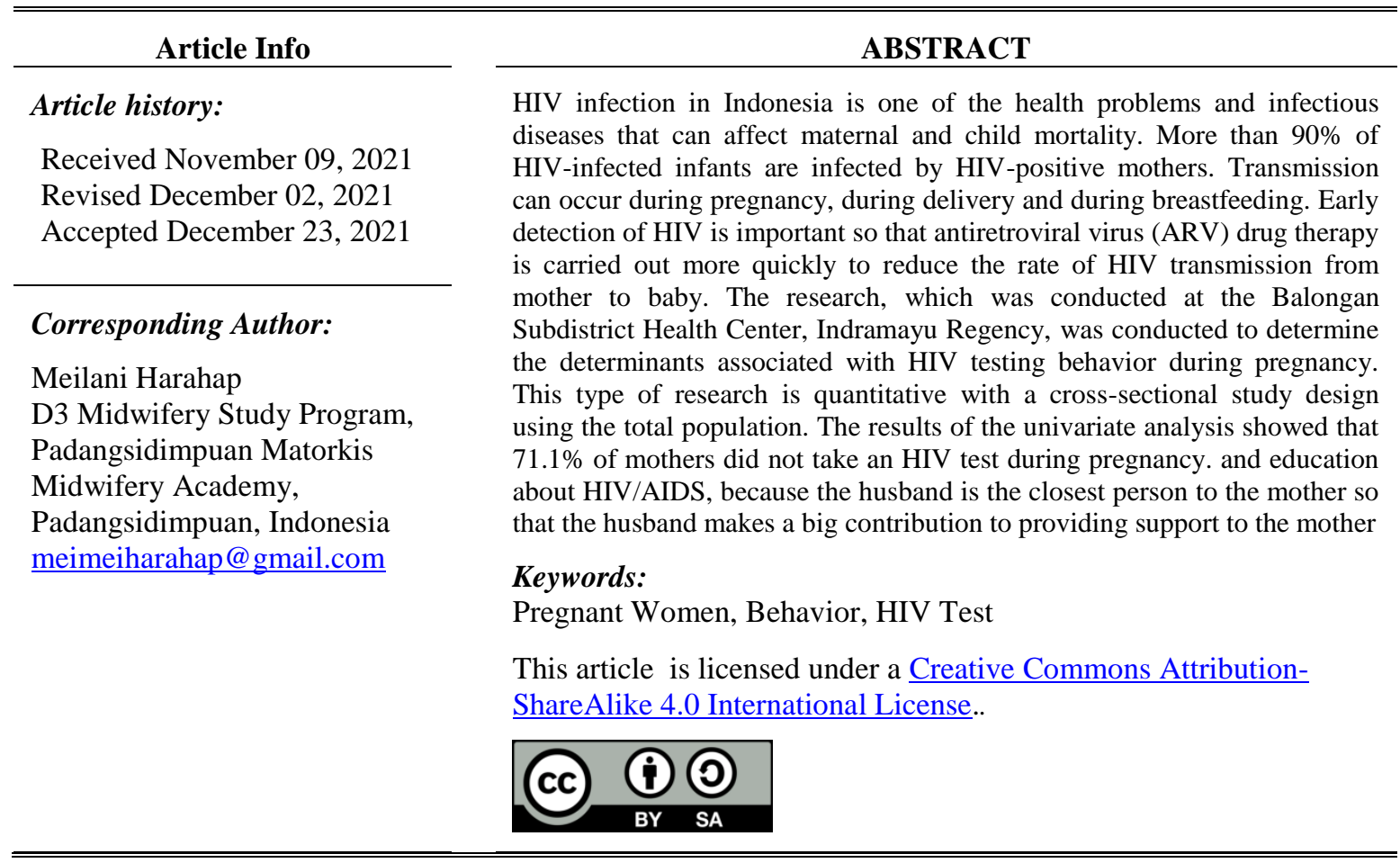

\section{INTRODUCTION}

HIV testing is one of the strategies in the Global Health Sector on HIV 2016-2021 in reducing the HIV epidemic. In the Circular of the Minister of Health No.1 of 2013 it was also stated that pregnant women need to do an HIV test which is the cause of AIDS to find cases of pregnant women who are infected with HIV. Anti Retro viral (ARV) drug therapy is done more quickly to reduce the rate of HIV transmission from mother to baby.

HIV/AIDS in pregnant women causes more serious problems because it can endanger the safety of the mother's life and is transmitted to the baby through pregnancy, during childbirth and breastfeeding. The number of pregnant women infected with HIV has increased. In 2011, the number was 534 people, which then increased to 1,182 people in January - June 2014. Meanwhile, the number of babies with HIV also increased, from 71 babies in 2011 to 86 babies in January - June 2014. Data from the Ministry of Health of the Republic of Indonesia in 2017 shows that out of 5,324,562 pregnant women in Indonesia, only 1,357,255 pregnant women underwent an HIV test, and 3,873 were positive for HIV infection, and were at risk of transmitting HIV to their babies. West Java Province was included in the top 3 most HIV cases in Indonesia in 2017. [7]

According to the 2019 recapitulation data from the Indramayu District Health Office, the prevalence of HIV cases for the Indramayu district was around 3,674 cases, the third highest in the province of West Java after Bandung and Bekasi. In accordance with the Regional Regulation of Indramayu Regency number 8 of 2009 concerning the prevention and control of HIV/AIDS, one of the activities is to carry out Voluntary Counseling \& Testing (VCT) activities. The working area of the Indramayu district health office consists of 49 health centers. The coverage of pregnant women amounted to 43,102 mothers, and 7,879 pregnant women or $18 \%$ of those who did the HIV test were covered. Balongan Health Center is one of the community health service centers that runs the PPIA program through HIV testing for pregnant women in Indramayu district. Of the several health centers in the district, the Balongan health center is one of the health centers with the highest number of pregnant women taking HIV tests. Data from 2018 shows that out of 981 pregnant women who had their pregnancy checked, only 91 or around $10 \%$ of pregnant women took an HIV test. [4]

Based on the description above, HIV testing is very important for the health of mothers and their babies. However, there are still a few women who do HIV tests at the Balongan Health Center, which is around $10 \%$, which is still far from the achievement target that should be $100 \%$. So that researchers feel it is important to conduct research on 
the behavioral determinants of HIV testing in pregnant women at the Balongan Health Center using the variables of age, education, knowledge, occupation, husband's support, support of health workers, information exposure and attitudes.

\section{METHOD}

The research design used was cross sectional. The population in this study were all postpartum mothers who were in the working area of the Balongan Health Center for the period June-July 2019 who visited the Posyandu and made home visits for those who were not present at the Posyandu and using Total Sampling obtained as many as 60 respondents. Data were obtained through questionnaires that were filled out by the respondents themselves. Data analysis using univariate, bivariate using chi square and multivariate multiple logistic regression with $(\square<0.05)$

\section{RESULTS AND DISCUSSION}

Table 1 Results of Bivariate Analysis

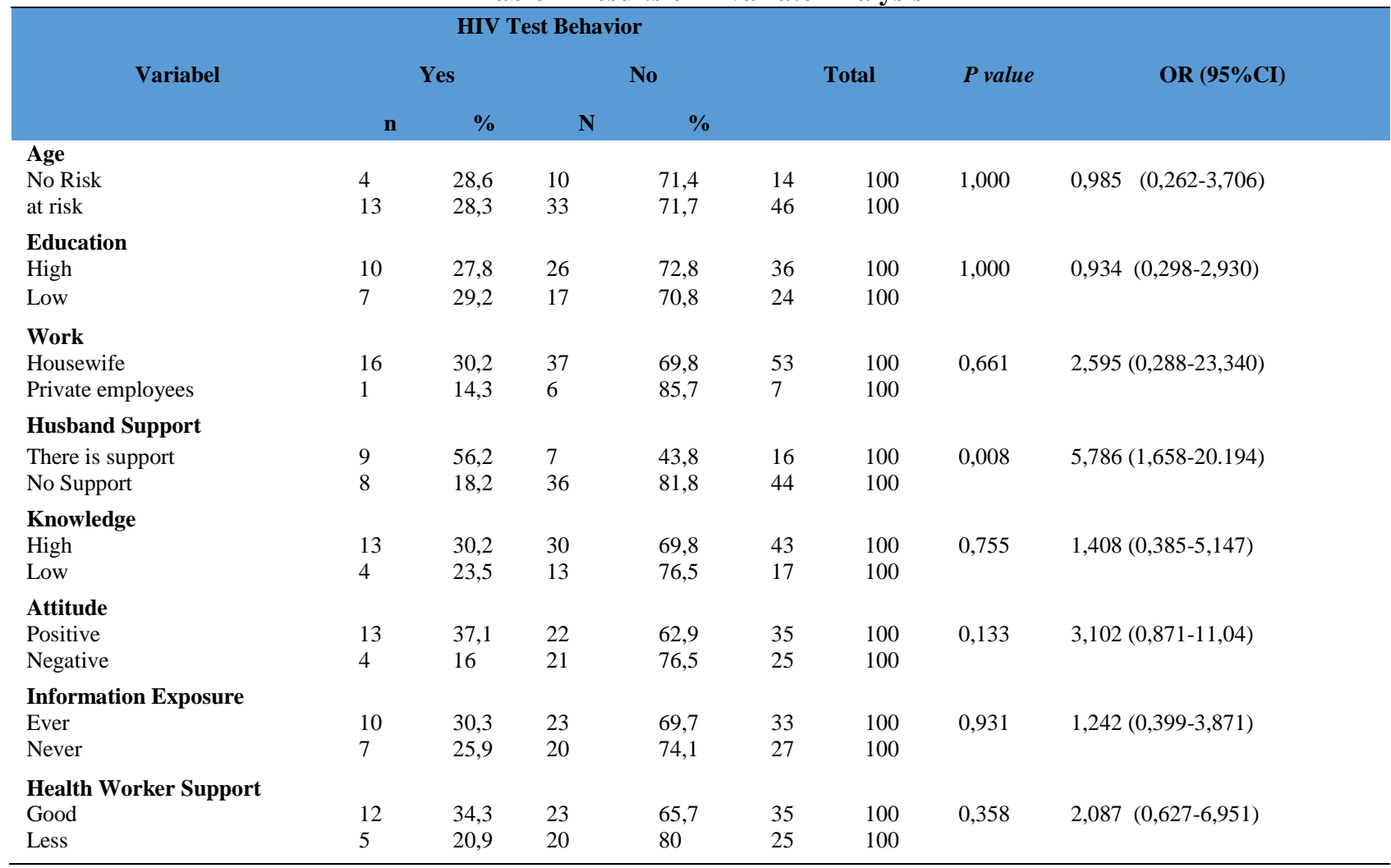

Table 2 Final Multivariate Analysis

\begin{tabular}{lcccc}
\hline \multicolumn{1}{c}{ Variabel } & P value & OR & Lower & Upper \\
\hline Husband's support & 0,013 & 6,293 & 1,485 & 26,668 \\
Age & 0,601 & 1,566 & 0,291 & 8,427 \\
Knowledge & 0,539 & 1,588 & 0,363 & 6,945 \\
Education & 0,461 & 0,588 & 0,144 & 2,410 \\
Job & 0,415 & 2,641 & 0,256 & 27,289 \\
Attitude & 0,169 & 2,687 & 0,657 & 10,985 \\
Health worker support & 0,093 & 3,391 & 0,814 & 14,121 \\
\hline
\end{tabular}

\subsection{Behavior of HIV testing in pregnant women}

The results of the study of 60 respondents were only $17(28.3 \%)$ respondents who took an HIV test during pregnancy, $3(17.6 \%)$ in the 1 st trimester only 1 respondent, in the 2 nd trimester only $2(11.8 \%)$ respondents and 12 (70, $6 \%$ ) respondents in the third trimester, while $43(71.7 \%)$ respondents did not take an HIV test during pregnancy.

In terms of knowledge, respondents already know enough information about HIV/AIDS, received support from health workers, but only a small proportion of respondents took an HIV test during their pregnancy. The reason that most respondents were asked why they didn't do the test was because there was no one to take the test, they didn't know there was a test, and they didn't feel it was important to do it, this was proven by the low number of respondents who Int Jou of PHE 
agreed with the statement that the mother had the possibility of contracting HIV in the attitude statement, out of 60 respondents only 4 respondents $(6.7 \%)$ strongly agree and 15 respondents $(25 \%)$ agree, while the others disagree and strongly disagree.

\subsection{Relationship of Age with HIV Testing Behavior}

The results showed $46(76.7 \%)$ respondents were not at risk (20-35 years) and $14(23.3 \%)$ were at risk $(<20$ years and $>35$ years), where age $>35$ years 4 respondents and $<20$ year 10 respondents.

Of the 60 respondents, 46 were not at risk, of which $13(28.3 \%)$ had an HIV test and $33(71.7 \%)$ did not. The results of the analysis showed that age was not related to HIV testing behavior with a P Value of 1,000, in line with the study of Humberto, et al, where age $<18$ years and ANC $<4$ visits were risk factors for not having an HIV test. This study is not in line with what Ekawati did, the age of the mother who is not at high risk is ready to get pregnant and is willing to control her pregnancy, including to do an HIV test. Mothers with an older age are able to make their own decisions, as is the case with the results of a study by Semali, et al, in Tanzania which stated that age as one of the variables did not show a significant relationship with acceptance of an HIV test. [3] [10]

In contrast to the study of Gebremedhin, et al and Alemu, et al in East Gojjam which stated that one of the variables that was significantly related to PITC was age. [1] [5]

Respondent's age was not related to HIV testing behavior because according to the researcher, there was information about HIV testing and support from health workers. Respondent's age $>35$ years is an older age that allows them to make their own decisions, including taking an HIV test.

\subsection{Relationship between Education and HIV Testing Behavior}

The results showed that of the 60 respondents, $36(60 \%)$ had higher education, of which $1(1.7 \%)$ had college education and $35(58.3 \%)$ had high school education. Respondents with low education were 24 (40\%), of which 20 $(33.3 \%)$ had junior high school education and 4 (6.7\%) had elementary school education.

The results showed that $10(27.8 \%)$ and $7(29.2 \%)$ had low levels of education. According to Worku, pregnant women who have higher education have acceptance of HIV testing, in contrast to the results of this study which was conducted that education was not associated with HIV testing behavior with a P value of 1,000, according to the results of research by Setiyawati and Meilani, in Yogyakarta, in line with this study, where one of the variables is education level where most of the respondents have $>12$ years of education, which is $81.4 \%$ but statistically, education level is not related to HIV testing behavior with $\mathrm{p}$ value $=0.291$. Respondents with secondary education or higher had five times higher odds of testing and receiving results during ANC compared to those with no education $(\mathrm{OR}=5.38,95 \% \mathrm{CI}$ 3,129.30, P < 0.001). Similar to the results of research by Ekawati, et al in Semarang that education has no effect on HIV testing behavior because the offer of health workers for HIV testing allows someone with low or high education to take an HIV test. [3] [11]

\subsection{Employment Relationship with HIV Testing Behavior}

From the results of the study, there were 16 (30.2\%) respondents as housewives who took HIV tests during pregnancy, while $1(14.3 \%)$ respondents who worked as private employees took HIV tests during pregnancy, but the results of the chi square test obtained a value $\mathrm{p}$ value $=0.666$ means that there is no relationship between mother's work and HIV testing behavior during pregnancy, as well as research conducted by Ekawati, et al which stated that one of the variables that was not related to HIV testing behavior of pregnant women at Bandarharjo Public Health Center Semarang City was work.[3]

This study is different from that conducted by Arniti et al. Bivariate analysis showed that acceptance by pregnant women was higher for mothers who did not work $(75.8 \%$; $\mathrm{p}=0.033$, OR $=2.82)$, similar to the results of Gazimbi et al. years in Zimbabwe where one of the factors associated with acceptance of an HIV test is employment. [2]

Mothers who do not work have more free time to do HIV tests, compared to mothers who work. The employment status of housewives is often considered not working because they are only at home, while housewives also have homework that even takes a lot of time so that mothers do not have time to visit or do pregnancy tests and HIV tests, plus a lack of susceptibility to disease and minimal knowledge make mothers ignore the HIV test even more.

\subsection{Relationship of Knowledge with HIV Testing Behavior}

The results showed that $43(71.7 \%)$ respondents had high knowledge, and $17(28.3 \%)$ respondents had low knowledge. $13(30.2 \%)$ respondents with high knowledge took an HIV test during pregnancy, while respondents with low knowledge were 4 (23.5\%) respondents. with HIV testing behavior during pregnancy.

Of the 12 questions filled in by respondents, question number 3 is the question that most respondents answered correctly, namely 51 respondents $(85 \%)$, with questions on how to transmit HIV/AIDS, while for the question with the lowest number of correct answers, there were 3, namely 31 respondents $(51,7 \%)$ with the question of the cause of HIV/AIDS, 39 (65\%) respondents with the question whether prevention of HIV transmission by performing a Caesarean section on HIV-infected mothers reduces the risk of infant infection, and $43(71,7 \%)$ respondents with the question whether the use of condoms can prevent HIV infection.

Although the knowledge of the respondents is quite high, there are still respondents who have the wrong knowledge that HIV is not a contagious disease and HIV can be cured. Not a few respondents who think wrongly that Int Jou of PHE 
PLWHA looks like a sick person. The wrong assumption that occurs in society is due to unclear and correct information about HIV-AIDS or because of low levels of education, so that understanding in managing the information received is not good.

This research is in line with research conducted by Setiyawati and Meilani, the level of knowledge of the majority of respondents is good knowledge, which is 54\%. However, this variable is also not related to behavior in carrying out HIV testing, in contrast to the study of Gebremedhin, et al in Ethiopia with one result which stated that mothers who had a higher level of knowledge about MTCT were more likely to receive PITC. [5] [11]

Knowledge has stages which include knowing, understanding, application, analysis, synthesis and evaluation. The respondent's level of knowledge may still be in the stage of not behaving. Good knowledge also does not necessarily change or influence the mother's behavior in taking an HIV test, but if it is possible to get support from health workers, family and friends, it can influence the mother's behavior in taking an HIV test.

\subsection{Relationship between Attitude and Behavior HIV Test}

The results showed that 35 respondents $(58.3 \%)$ had a positive attitude towards HIV/AIDS and 25 (41.7\%) respondents had a negative attitude, where 15 respondents $(25 \%)$ strongly agreed that it is important to seek information about HIV/AIDS and 13 respondents $(21.7 \%)$ felt that it was important for all housewives to have an HIV test and know that one of the ways to prevent transmission is to have sexual intercourse without changing partners. In the statement of the possibility of contracting HIV/AIDS, only 4 respondents $(6.7 \%)$ strongly agree and 15 respondents (25\%) agree, while the others disagree and strongly disagree. The possibility of individuals taking preventive action depends on their belief in their susceptibility to certain diseases, from the results of the questions above, the respondent feels vulnerable to HIV, thus enabling the respondent not to take an HIV test.

The results of the analysis of the relationship between attitudes and behavior on HIV testing of pregnant women were obtained by $13(37.1 \%)$ respondents with positive attitudes who took HIV tests during pregnancy, while respondents with negative attitudes were $4(16 \%)$. The results of the chi square test obtained a $\mathrm{p}$ value $=0.133$, meaning that there was no relationship between attitudes and HIV testing behavior during pregnancy, in line with research by Setiyawati and Meilani where attitudes were not related to HIV testing ( $p$ value $=0.260$ ). In Hartini's study, attitudes were also obtained that were not related to the behavior of pregnant women to use VCT services, in contrast to the research of Halim, et al, and Gebremedhin, et al, which found that attitudes had a relationship with HIV test acceptance.[5]

\subsection{Relationship between Health Worker Support and HIV Testing Behavior}

The results of the analysis showed that 35 respondents $(58.3 \%)$ received support from health workers and 25 (41.7\%) did not receive support from health workers. The results of the analysis of the relationship between the support of health workers and the behavior of HIV testing for pregnant women showed that $12(34.3 \%)$ respondents received support from health workers who did HIV tests during pregnancy, while 5 (20.9\%). The results of the chi square test obtained $\mathrm{p}$ value $=0.358$, which means that there is no relationship between the support of health workers and the behavior of HIV testing during pregnancy. This study is in line with the research of Arniti, et al. The analysis shows that one of the factors that statistically does not significantly increase the acceptance of HIV testing is the support of health workers, because the variables of husband's support, perception of disease severity, mother's employment status are variables that more influence the acceptance of HIV tests in Denpasar City Health Center.[2]

In the sixth statement, 52 respondents $(86.7 \%)$ received assistance and explanations needed to carry out examinations at the posyandu, while in the fourth statement only 30 respondents (50\%) were offered an HIV test.

Isni's research, obtained the results of research in Central Java that there is a significant relationship between the support of health workers and the behavior of HIV mothers in preventing HIV/AIDS transmission from mother to baby, obtained $\mathrm{p}$ value $=0.010$, because $\mathrm{p}$ value 0.05 . [6]

The support of health workers referred to in this study in supporting pregnant women in carrying out HIV tests, one of which is providing information about HIV, suggestions for examinations. The role of health workers is very influential, because officers often interact, so that understanding of physical and psychological conditions is better, interacting frequently will greatly affect the sense of trust and acceptance of the presence of officers for themselves.

In this study, the support of health workers was not related to the behavior of HIV testing in pregnant women, because other factors such as perceptions of benefits and perceptions of self-susceptibility could influence mothers not to take the test, as evidenced by the attitude of mothers who disagreed about their chances of contracting the infection. HIV/AIDS. Another factor that allows respondents not to take an HIV test is respondents who do not receive support from their partners/husbands, in this study most of the respondents were not accompanied by their husbands during their pregnancy check-ups.

\subsection{Relationship of Husband's Support with HIV Testing Behavior}

The results of the analysis of 60 respondents, 44 respondents $(73.3 \%)$ did not receive support from their husbands during their pregnancy check-ups, while 16 respondents $(26.7 \%)$ other respondents received support during their pregnancy check-ups.

The results of the analysis of the relationship between husband's support and HIV testing behavior of pregnant women obtained $9(56.2 \%)$ respondents who were accompanied by their husbands and participated during the examination who took an HIV test during pregnancy, while those who were not accompanied by 8 (18.2\%) who took an Int Jou of PHE 
HIV test during pregnancy . The proportion of mothers who had an HIV test accompanied during a pregnancy check-up was higher than the proportion of mothers who were unaccompanied. The results of the chi square test obtained $p$ value $=0.013$, meaning that there is a relationship between husband's support and HIV testing behavior during pregnancy.

This study is in line with the results of a study conducted by Tchamba on 26 HIV-infected women with a qualitative design which revealed that $27 \%$ of women received emotional support in the form of being loved and cared for by their mother, $19 \%$ of women received encouragement from their older sister, 19\% of women received all support from their husbands, while others did not get support from their families, as was the case with Elisa et al.'s research, year. In addition, it is also supported by research by Nurhayati, Arniti with OR $=8.71$ (95\% CI: 2.89-26.28), in contrast to the research of Ekawati, et al. health during pregnancy check-ups.[2] [3] [9]

\subsection{Relationship of Information Exposure to HIV Testing Behavior}

The results obtained from 60 respondents obtained that 33 respondents $(55 \%)$ had been exposed to information and $27(45 \%)$ respondents had never been exposed to information about HIV/AIDS. the fourth statement has the highest number of 32 respondents $(53.3 \%)$, where the source of information is obtained from print, electronic, or online media. In statements 1 and 2, $30(50 \%)$ respondents stated that they had received counseling at the Puskesmas about HIV/AIDS and $30(50 \%)$ other respondents had never.

The results of the analysis of the relationship between exposure to information and the behavior of pregnant women with HIV testing showed that 10 (30.3\%) respondents had been exposed to information by taking an HIV test during pregnancy, while $7(25.9 \%)$. The results of the chi square test obtained a p value $=0.931$, meaning that there is no relationship between information exposure and HIV testing behavior during pregnancy, in contrast to Novianti's research which states that information is a factor that influences pregnant women to test for HIV with an OR $=12.03$ and Semali's study in Tanzania that receiving information about HIV during ANC was associated with acceptance of an HIV test with $\mathrm{p}<0.001$. [8]

Each respondent is different in processing the information obtained, the information conveyed may not necessarily affect the mother's behavior in carrying out an HIV test, this can be influenced by the respondent's attitude towards HIV/AIDS which is considered taboo, the education level of each respondent and the influence of support, both from staff health, family and friends.

\subsection{Dominant Variable in Research}

The results of the multivariate analysis showed that the statistical test with a significance level of $5 \%$ obtained a $\mathrm{p}$ value of 0.013 , which means that there is a statistically significant relationship between husband's support and HIV testing behavior. The role of the husband referred to in this study in supporting pregnant women to carry out HIV checks is one of them by taking them to ANC services at the puskesmas. The husband's role also includes accompanying during the HIV test, where the OR value $=6.2$, meaning that mothers who receive support from their husbands have a 6.2 higher chance of taking an HIV test than mothers who do not receive support.

\section{CONCLUSION}

Provide a statement that what is expected, as stated in the "INTRODUCTION" section can ultimately result in "RESULTS AND DISCUSSION" section, so there is compatibility. Moreover, it can also be added the prospect of the development of research results and application prospects of further studies into the next (based on result and discussion).

Provide counseling and education about HIV/AIDS to husbands, because husbands are the closest people to mothers, so husbands make a big contribution to providing support to mothers. Provide test examination facilities outside the working hours of the puskesmas managed by midwives in each village.

It is recommended to be able to conduct an in-depth study to determine the behavioral determinants of HIV testing and add the Health Believe Model (HBM) theory that can influence a person's behavior and conduct an in-depth study of the information exposure variable, where the information exposure variable should be accompanied by a question when the respondent obtained the information. It is also recommended to use a combination of two types of research, namely quantitative and qualitative. The targets are not only for mothers, but also for husbands, families and health workers.

\section{ACKNOWLEDGEMENTS}

Author thanks Nikmatul Khoiriyah Pulungan, Ennysah Hasibuan most cases, sponsor and financial support.

\section{REFERENCES}

[1] Alemu, et al, "Utilization of HIV testing services among pregnant mothers in low income primary care settings", 2017 in northern Ethiopia: a cross sectional study, https://bmcpregnancychildbirth.biomedcentral.com/track/pdf/10.1186/s12884-017-1389-2,

[2] Arniti, et al, "Factors Associated with Acceptance of HIV Tests by Pregnant Women at Denpasar City Health Center", 2014, https://ojs.unud.ac.id

[3] Ekawati, et al "Behavioral Determinants of HIV Testing for Pregnant Women at Bandarharjo Health Center Semarang City", 2016, http://etd.repository.ugm.ac.id

[4] Indramayu District Health Office, "Feedback Report HIV counseling and testing activities", 2018.

[5] Gebremedhin,et al, "Factors associated with acceptance of provider-initiated HIV testing and counseling among pregnant women in Ethiopia, 2017 : https://www.dovepress.com/factors-associated-with-acceptance-of-provider-initiated-hiv-testing-a-peer-reviewed-fulltext-article-PPA\#

Int Jou of PHE 
[6] Isni, "Family Support, Support of Health Workers, and Behavior of HIV Mothers in Prevention of Transmission of HIV/AIDS to Infants", 2016: https://journal.unnes.ac.idnjuindex.phpkemasarticleviewFile40144682

[7] Indonesian Ministry of Health, "Indonesia Health Profile Data and Information 2017", Accessed from 2018 http://www.pusdatin.kemkes.go.id/resources/download/pusdatin/profil-kesehatan-indonesia/Data-dan-Informasi_Profil-Kesehatan-Indonesia2017.pdf?opwvc=1, Regulation of the Minister of Health of the Republic of Indonesia Number 21 of 2013 concerning the prevention of HIV and AIDS

[8] Novianti, "Factors Associated with HIV Testing Behavior in Pregnant Women", Bandung, West Java : library FKM UI, 2017

[9] Nurhayati, "Factors related to the participation of pregnant women in VCT examinations at community health centers", 2016 https://www.researchgate.net/publication/328785805_faktor

faktor_yang_berhubungan_dengan_keikutsertaan_ibu_hamil_dalam_pemeriksaan_vct_di_puskesmas_guguk_panjang/download

[10] Semali, et al, "Factors associated with HIV testing and receiving results during antenatal care in Tanzania", 2014, http://www.bioline.org.br/pdf?ep14048

[11] Setiyawati, Meilani, "Behavioral Determinants of HIV Testing in Pregnant Women", 2015: http://journal.fkm.ui.ac.idkesmasarticleview565448 [Cited october 212021$]$

[12] Turan, et al, "HIV/AIDS Stigma and Refusal of HIV Testing Among Pregnant Women in Rural Kenya: Results from the MAMAS Study", 2011. https://www.ncbi.nlm.nih.gov/pmc/articles/PMC312702

[13] Ardhiyanti, Y, “AIDS Teaching Materials in Midwifery Care”, Yogyakarta: Deepublish, 2015.

[14] Irianto K," Epidemiology of Communicable and Non-Communicable Diseases Clinical Guide", Bandung: ALVABETA, 2014.

[15] Dewi M, dan Wawan A, "Theory \& measurement of knowledge of human attitudes and behavior", Yogyakarta. Nuha medika, 2010

[16] Ministry of Education, "Indonesia Dictionary”, Jakarta: Balai Pustaka, 2007

[17] Ministry of Health Republic of Indonesia, "Training Module on Prevention of Mother to Child Transmission of HIV/AIDS, Jakarta, 2008

[18] Maryunani A, Aeman U, "Prevention of Mother-to-Baby Transmission of HIV: Management in Midwifery Services", Jakarta: CV. Trans Info Media; 2013

[19] Notoatmodjo, S, "Health Research Methodology”, Jakarta : Rineka Cipta, 2010.

[20] Wiley J, Limited S, “Sexual Health”, Jakarta: Bumi Medika; 2014.

[21] Iswanto L, "Indonesian women's knowledge about HIV/AIDS”, populasi, Vol 20 No. 1, pp 68-75, 2011

[22] Nursalam, Kurniawati, "Nursing Care for HIV/AIDS-Infected Patients”, Jakarta : Salemba Medika, 2009.

[23] Nursalam, "Concept and application of Nursing Research Methodology”, Jakarta : Salemba Medika, 2008.

[24] Azwar, S, "Human attitude, theory and development”, Yogyakarta : Pustaka Pelajar, 2003.

[25] Danim, S, "Research Methods for the Behavioral Sciences", Jakarta : Bumi Aksara, 2004.

[26] Effendi, Makhfudli, "Nursing Community Health Nursing Theory and Practice", Jakarta : Salemba Medika, 2009. 